\title{
Taura syndrome virus in specific pathogen-free Penaeus vannamei originating from Hawaii and in P. vannamei stocks farmed in France?
}

\author{
Donald V. Lightner ${ }^{1, *}$, Allen Riggs ${ }^{2}$, John S. Corbin ${ }^{2}$, Anthony C. Ostrowski ${ }^{3}$ \\ ${ }^{1}$ Department of Veterinary Science and Microbiology, The University of Arizona, Tucson, Arizona 85721, USA \\ ${ }^{2}$ Hawaii Aquaculture Development Program, 1177 Alakea Street \#400, Honolulu, Hawaii 96813, USA \\ ${ }^{3}$ The Oceanic Institute, 41-202 Kalanianaole Highway, Waimanalo, Hawaii 96795, USA
}

\section{TSV IN SPF SHRIMP FROM HAWAII?}

Do et al. (2006) recently reported in Diseases of Aquatic Organisms (DAO) that their lab (The National Fisheries Research and Development Institute [NFRDI]; also referred to as the National Fisheries Research Center [NFRC] elsewhere in this Comment) had detected Taura syndrome virus (TSV) in 'stocks of $P$ [enaeus]. vannamei imported from Hawaii.' They named this TSV isolate KOR-ImPv05TSV. This report of the detection of TSV in stocks of $P$. vannamei (also known as Litopenaeus vannamei) (Farfante \& Kensley 1997) from Hawaii is not only incorrect, but it is also disturbing because the virus has not been detected in Hawaii since 1994 when it was reported as the cause of a disease outbreak at a shrimp culture facility located near the village of Kahuku on the Island of Oahu, Hawaii (Brock et al. 1995, Lightner et al. 1995). Brock et al. (1995) indicated in their report that TSV had been detected at 'a shrimp farm in Kahuku, Oahu, Hawaii in May of 1994.' In the same paper, and in a subsequent review paper on Taura syndrome (Brock 1997), the authors stated that 'since mid 1995 Taura syndrome has not re-occurred in Kahuku, Oahu, Hawaii.'

As was indicated in his reviews of Taura syndrome (Brock 1997, Brock et al. 1997), the disease was successfully eradicated from the infected farm at Kahuku and, hence, from Hawaii. The absence of Taura syndrome and TSV in Hawaiian shrimp farms and in the shrimp stocks cultured in those facilities has been confirmed by a routine testing and surveillance program administered by the Hawaii Aquaculture Development
Program (ADP-HI). This program has been in place and active for more than $10 \mathrm{yr}$. The development of specific pathogen-free $(\mathrm{SPF}=$ free of TSV and other shrimp diseases listed by the World Animal Health Organization [OIE], see OIE 2006) shrimp stocks by the Oceanic Institute and the distribution and culture of these stocks by the shrimp culture industry in Hawaii has earned Hawaii a reputation for producing and exporting only SPF shrimp since the stocks were introduced to the industry about 15 yr ago (Wyban et al. 1993, Pruder et al. 1995, Moss et al. 2003, 2005).

Since the outbreak (and subsequent eradication) of Taura syndrome at the shrimp farm in Kahuku, Oahu, Hawaii, all of the shrimp farms on the 4 Hawaiian Islands (Oahu, Kauai, Molokai, and Hawaii) that produce and export shrimp broodstock have been participants in the disease screening and surveillance programs run by the ADP-HI. Taura syndrome (and its virus TSV) has not been found in routine screening of Penaeus vannamei (or in other penaeid species also reared at some of the facilities). This routine screening is required for health certificates, which accompany exported consignments of live $P$. vannamei broodstock.

According to ADP-HI, there were no complaints from any importing country regarding broodstock exports from Hawaii in 2004, 2005 or 2006. ADP-HI records show that export health certificates for consignments of shrimp broodstock to South Korea were issued to only one Hawaiian company in 2005. Furthermore, according to correspondence provided by the producer (who asked not to be named) of the disputed shipment described in Do et al. (2006) as 'stocks of 
Penaeus vannamei imported from Hawaii,' the 'stocks' that were reported to test positive for TSV consisted of a sample of 10 adult $P$. vannamei broodstock which were sent to the 'National Fisheries Research Center (NFRC)' on February 24, 2005, as a pre-shipment sample for testing. On March 21, 2005, an employee of the Korea Freight Company reported that NFRC had detected TSV in the pre-shipment sample and that orders for shipments of $P$. vannamei broodstock that were to be sent through that company to several producers in Korea (including the NFRC) were canceled. Upon receiving the news from the Korea Freight Company (and not directly from NFRC), the supplying company in Hawaii disputed the finding and requested (through the Korea Freight Company to NFRC) that additional samples from the same stock be provided to NFRC for additional testing or that the NFRC seek a second opinion with the likely 'false positive' results for TSV they had reported. There was no response from the Korea Freight Company to the request for retesting, nor has there been any further communication between the producer in Hawaii and any of the clients who were to have received broodstock shipments in early 2005.

Another significant issue with Do et al. (2006) is in their recognition that the sequence analysis of the TSV isolate that NFRDI found in Korean shrimp farms in 2004, and named KOR-CsPv04TSV, and the isolate KOR-ImPv05TSV said to be from Hawaii, were more closely related to TSV isolates from Thailand (Nielsen et al. 2005) than to any of the other TSV genotype clusters originating from the Americas or elsewhere in Asia (Tang \& Lightner 2005). Furthermore, the authors indicated that Korea imported broodstock from other countries with the statement (on page 173, column 1, paragraph 3) 'Within the last few years, bloodstock [sic] $P$. vannamei has been imported from various countries.' No additional information is provided by the authors about which countries were the source of the imported broodstock, but they did imply that the source of TSV in Korea was Asia rather than Hawaii with the statement (on page 173, column 1, paragraph 2, last sentence) '... this finding indicates that the members of Group 1 [which are all Thai genotypes of TSV; see Fig. 2 in Do et al. (2006)] may be responsible for the epizootics of shrimp in Korea.'

Although the authors state that they believe that TSV was introduced with imported broodstock and that the genotype of the 2 Korean isolates of TSV are more closely related to isolates from Thailand than any other source, they nonetheless ignored the very likely possibility that the Korean TSV isolates came from a source in SE Asia, and they instead chose to identify Hawaii as the most likely source of the virus. This was done without confirmation of the diagnosis of TSV in the sample of broodstock from Hawaii with a second sample or by an independent laboratory (which was requested by the producer in Hawaii). In addition, this action by the NFRDI (a laboratory of the Korean Government) did not follow OIE guidelines, as specified in Section 1.3 (Obligation and Ethics in International Trade) of the Aquatic Animal Health Code (OIE 2006), by failing to notify the Competent Authority (USDA APHIS, and ADP-HI as the Co-Competent-Authority) of the detection of TSV in stocks which had been certified as free of TSV (as well as other OIE-listed shrimp diseases) by the Hawaii Aquaculture Development Program.

\section{TSV IN PENAEUS VANNAMEI CULTURED IN FRANCE?}

In Fig. 2, Do et al. (2006) list a number of TSV isolates from different geographic regions. Some of the isolates are of particular relevance to the present paper and to the authors' claim (on p. 172, column 1, paragraph 1) to have '... detected TSVs from stock of $P$ [enaeus]. vannamei imported from Hawaii.' Among these is a reference to 'FrPvTSV (P. vannamei, France), AF277675.' Reference to this isolate is particularly noteworthy, especially in the context of the validity of the data presented and conclusions reached by the authors, because there is no such isolate. The TSV isolate comprising GenBank accession number AF277675 is the same isolate shown in Fig. 2 as 'HI94TSV.' The references listed with the GenBank accession numbers for the sequence information for 'Hawaiian' and 'French' TSV isolates used by the authors in their analysis clearly indicate that AF510518 (Erickson et al. 2005) is a $1164 \mathrm{bp}$ portion of the TSV VP1. This sequence is $100 \%$ identical to the sequence for VP1 within the entire TSV genome sequence given by Mari et al. (2002) in AF277675. The TSV isolate represented in AF277675 and AF510518 is HI94TSV, and this is the original TSV isolate from the TSV outbreak reported from the TS disease outbreak (in May 1994) at a shrimp culture facility located near the village of Kahuku on the Island of Oahu, Hawaii (Brock et al. 1995, Lightner et al. 1995, Bonami et al. 1997, Mari et al. 2002). Furthermore, no shrimp farms in France have ever cultured P. vannamei, nor has Taura syndrome of TSV been detected or reported from France (J. Bonami pers. comm., June 19, 2006). To summarize the points being made here: Although the person submitting the TSV sequence AF277675 to GenBank (J. Mari) had a French address, that fact in no way implies that the TSV isolate originated in France. As was reported in the publication (Mari et al. 2002) cited with AF277675, that isolate was obtained from Hawaii in 1995. 


\section{SUMMARY}

It is the opinion of the authors of this Comment on Do et al. (2006), that those authors incorrectly interpreted their test results, which are more likely the result of mislabeling of samples or within-laboratory contamination, and that the TSV isolates found in Penaeus vannamei in Korea in 2004 and 2005 did not originate from Hawaii as claimed by the authors, but from a country (or countries) in southeast Asia. Finally, we believe that the authors did not follow proper international guidelines, extend a professional courtesy to the supplier of the disputed shrimp sample, nor take a critical approach in interpreting their own data. It is unfortunate that the authors did not follow through with additional testing, or seek a second opinion from an independent laboratory, before implicating shrimp imported from Hawaii as the source of TSV in Korea.

\section{LITERATURE CITED}

Bonami JR, Hasson KW, Mari J, Poulos BT, Lightner DV (1997) Taura syndrome of marine penaeid shrimp: characterization of the viral agent. J Gen Virol 78:313-319

Brock JA (1997) Special topic review: Taura syndrome, a disease important to shrimp farms in the Americas. World J Microbiol Biotechnol 13:415-418

Brock JA, Gose R, Lightner DV, Hasson KW (1995) An overview on Taura syndrome, an important disease of farmed Penaeus vannamei. In: Browdy CL, Hopkins JS, (eds) Swimming through troubled water. Proceedings of the special session on shrimp farming, Aquaculture '95. World Aquaculture Society, Baton Rouge, LA, p 84-94

Do JW, Cha SJ, Lee NS, Kim YC, Kim JW, Kim JD, Park JW (2006) Taura syndrome virus from Penaeus vannamei shrimp cultured in Korea. Dis Aquat Org 70:171-174

Erickson HS, Poulos BT, Tang KFJ, Bradley-Dunlop D, Lightner DV (2005) Taura syndrome from Belize represents a unique variant. Dis Aquat Org 64:91-98

Editorial responsibility: Managing Editor
Farfante P, Kensley BF (1997) Penaeoid and sergestoid shrimp and prawns of the world: keys and diagnoses for the families and genera. Mem Mus Natl Hist Nat 175:1-233

Lightner DV, Redman RM, Hasson KW, Pantoja CR (1995) Taura syndrome in Penaeus vannamei (Crustacea: Decapoda): gross signs, histopathology and ultrastructure. Dis Aquat Org 21:53-59

Mari J, Poulos BT, Lightner DV, Bonami JR (2002) Shrimp Taura syndrome virus: genomic characterization and similarity with members of the genus Cricket paralysis-like viruses. J Gen Virol 83:915-926

Moss SM, Moss DR, Arce SM, Otoshi CA (2003) Disease prevention strategies for penaeid shrimp culture. In: Sakai Y, McVey JP, Jang D, McVey E, Caesar M (eds) Proceedings of the 32nd US Japan Symposium on Aquaculture. USJapan Cooperative Program in Natural Resources (UJNR). US Department of Commerce, NOAA, Silver Spring, MD, p 34-46. Available at: www.lib. noaa.gov/japan/aquaculture/aquaculture_panel.htm

Moss SM, Doyle RW, Lightner DV (2005) Breeding shrimp for disease resistance: challenges and opportunities for improvement. In: Walker P, Lester R, Bondad-Reantaso MG (eds) Diseases in Asian aquaculture V. Asian Fisheries Society, Manila, p 379-393

Nielsen L, Sang-oum W, Cheevadhanarak S, Flegel TW (2005) Taura syndrome virus (TSV) in Thailand and its relationship to TSV in China and the Americas. Dis Aquat Org 63:101-106

OIE (World Animal Health Organization) (2006) Aquatic animal health code. OIE Aquatic Animals Commission. Paris. Also available at: www.oie.int/eng/normes/en_acode.htm

Pruder GD, Brown CL, Sweeney JN, Carr WH (1995) High health shrimp systems: seed supply - theory and practice. In: Browdy CL, Hopkins JS (eds) Swimming through troubled water. Proceedings of the special session on shrimp farming, Aquaculture '95. World Aquaculture Society, Baton Rouge, LA, p 40-52

Tang KF, Lightner DV (2005) Phylogenetic analysis of Taura syndrome virus isolates collected between 1993 and 2004 and virulence comparison between 2 isolates representing different genetic variants. Virus Res 112:69-76

Wyban JA, Swingle JS, Sweeney JN, Pruder GD (1993) Specific pathogen free Penaeus vannamei. World Aquacult 24:39-45

Submitted: September 27, 2006; Accepted: December 11, 2006 Proofs received from author(s): December 22, 2006 